\title{
ALKATI Positive
}

National Cancer Institute

\section{Source}

National Cancer Institute. ALKATI Positive. NCI Thesaurus. Code C150446.

An indication that expression of ALKATI has been detected in a sample. 